Reviews

themselves in a difficult moral situation according to Xikrin standards. Fisher states:

The expectations created by the Xikrin social organization put chiefs in a position where they must supply goods to commoners but simultaneously are de-authorized from converting surplus produced by commoners into the means of social control. (p. 125)

Fisher points out the different perceptions between commoners and chiefs about the redistribution process. Chiefs emphasize how they are redistributing goods according to the "morality of kinship," for the good of the community, yet commoners calculate the generosity of chiefs in terms of who "pays well" (p. 187). The chief's role is viewed differently between commoners and chiefs reflecting the changes in recent years. Fewer men aspire to be chiefs because of the increasing contradictions of the position. They must be able to negotiate relationships with outsiders and among their own people as able leaders who can coordinate both secular and ritual activities, which involve these trade goods. In order to obtain trade goods they must sell the natural resources within Xikrin land holdings and be able to control the negotiations with outsiders, in order to maintain the respect of commoners.

Tensions and contradictions exist between men and women, also, because women perceive that recent changes are affecting them negatively. They only obtain some foods, especially game, through their relationships with men, especially their spouses. This becomes significant with the rise in female-headed households in recent years and with the increasing self-sufficiency of young men who are able to acquire trade goods from the chiefs. Further, some chiefs now hire poor Brazilians to work as gardeners, which undermines domestic production by women because of the potential breakdown of the chiefs' reciprocal obligations to them. Women actively resist chiefly authority to redistribute by appealing to FUNAI to give goods directly to individual workers, including women, rather than to the chiefs. They also refuse to work enthusiastically in the chiefs' collective gardens, despite the encouragement of their male kin, because only the men would receive the trade goods for their cooperation. Fisher points out that women do not oppose the influx of trade goods into their society, but they resist their increasing dependence upon men and the chiefs for trade and subsistence goods. Thus, we should see the divergence of men's and women's opinions and initiatives "as part of a complex interplay of contradictory social trends rather than as something given by a cultural charter for masculinity or femininity" (p. 192).

These examples only scratch the surface of Fisher's highly readable and nuanced text. He reminds the reader of the importance of recognizing that a political ecology approach must include the social, historical and political as well as the natural environmental. It is only through using such an approach, he argues, that we can truly understand why such groups as the Kayapó continue to allow the extraction of natural resources upon which their livelihoods depend, and to assist them in coming up with viable alternatives. Fisher makes the case that any solution-making process must recognize the external and internal political economies involved.

\title{
Democracy and Development in Mali. Edited by R. James Bingen, David Robinson, and John M. Staatz. East Lansing: Michigan State University Press (2000), 352 pp.
}

\section{Reviewed by Dolores Koenig, Department of Anthropology, American University, Washington, DC.}

In May 1998, Alpha Oumar Konaré, president of Mali, was granted an Honorary Doctor of Humanities degree by Michigan State University (MSU). In light of President Konaré's commitment to learning, MSU held a one-day academic symposium to celebrate both the commitment and the achievements of the president and his wife. Some of these presentations are assembled in this volume, Democracy and Development in Mali, which emphasizes the scholarly work of MSU faculty and present and former students. The only contributions by non-MSU affiliated persons are by Adame Ba Konaré (a noted historian and the president's wife), Cheick Oumar Diarrah (ambassador from Mali to the United States), and David Rawson (then ambassador from the United States to Mali).

One might ask whether honoring a president might lead to a volume of limited usefulness, one that would inflate Mali's achievements or discuss only the positive. While it is indeed true that no harsh critics of Konaré's administration are included, the pieces generally represent very sound scholarship. They include articles by some of the foremost scholars of contemporary and historical Mali, among them people I systematically turn to for my own background reading. As I perused the book, I realized that I had in fact read a significant number of these pieces in earlier report form and found them important and useful. The articles here feature the latest thinking on the specialties of the authors are by no means puff pieces to please politicians. 
Reviews

The volume concentrates on history and social science, agricultural development, and political studies of democratization, specializations reflecting the strengths of the scholars affiliated with MSU,. While these perspectives may not represent a true cross-section of contemporary scholarship on Mali, they are important areas of inquiry. In any case, contemporary scholarship on Mali investigates so many varied questions that no single volume could do justice to them all. The strengths of MSU are as good a place as any to start. Readers of the Journal of Political Ecology, however, should note that while the political and economic are quite emphasized, the ecological receives much less attention.

The first section of the book addresses cultural and historical issues; with one exception (an anthropologist), the articles are by historians. The volume begins with an article by A.B. Konare, who looks at the selectivity of collective memory in contemporary Mali and its uses for both positive and negative purposes. D. Robinson's article focuses on three colonial administrators in Senegal, Mali, and Mauritania, stressing the way in which these ambitious men were able to pursue their own visions of colonial change by deliberately cultivating certain allies (both in metropolitan France and locally) and by playing off opposition groups against one another (again in both places). J. Hanson's study of generational conflict looks at two generations of soldier-followers of the 19th century Islamic leader, Al-Hajj Umar Tal. After initial conquests, the first generation of soldiers settled down in conquered areas, taking up commercial farming; when outside threats induced leaders to recruit new soldiers more committed to jihad than to personal gain, tensions arose. G. Lydon discusses the studies done for the Popular Front government in the 1930s by a French woman, Denise Moran Savineau, with the goal of improving the situation of women in the colonies. Finally, M. Grosz-Ngaté analyzes why Malian villagers encouraged the migration of young men but discouraged that of young women, showing how this trend is linked to patterns of family patrimony that include young men but exclude young women.

Although these articles cover diverse topics, they are united by a view of culture as an institution in which social groups participate differentially. Hence men and women, youth and elders, those of different ethnic background, those with different economic or political interests, usually benefit unequally from existing cultural and social institutions. Individuals do not necessarily take cultural constraints as given, but manipulate them as active agents, with responses that may range from support to resistance. This is an important perspective for Malian cultural scholarship, which sometimes tends to reify cultural ideologies and traditions. These articles taken together show that Malians have faced significant change for a long time.

The second section focuses on economic and agricultural policy reform. This section is more focused than the first one because the articles are by agricultural economists, Malian and American (J. Dioné, N.N. Dembélé, S.B. Diarra, G. Dimithè, J. Staatz, J. Tefft), who have worked together and sequentially on a series of Mali-MSU projects on the effects of contemporary policy reforms. These articles address the effects on production and trade of major Malian crops (coarse food grains [millet, sorghum, maize], rice, cotton) of recent policy changes meant to liberalize markets, prices, and distribution. The articles raise common issues. First is the ineffectiveness of prices alone to create incentives for increased farm production; rather these need to be complemented by improved technologies and institutions that improve farmer access to them. This is shown in two contrasting cases: rice, where technologies and institutions encouraged quite dramatic production increases in response to liberalized prices, versus coarse grains, where lack of more productive technologies, agricultural extension, and targeted credit facilities correlated with very slow growth. Second is the emphasis on the changes in commercial distribution circuits created by liberalization and their effects. Of particular interest is the way in which liberalization opened up possibilities for small-scale distributers (grain traders) and processors (rice millers) and broke the control of a few large intermediaries - to the benefit of both consumer and producer. Third is a concern for the ways in which market imperfections (especially transport and information difficulties) created an economic context that favored flexible, small-scale processors and traders over large-scale, less flexible ones. Fourth, analysis of farm production is placed in the context of intimate knowledge of Malian farm households and the cultural underpinnings and conflicting interests in them, for example, the divisions between elders and youth, or the relationships between men and women.

The agricultural economists associated with MSU, both Malian and American, have perhaps done some of the strongest work on recent changes in Malian agriculture. These are impressive empirical studies with fine data. I have long consulted much of this work in the form of unpublished reports. Evidently, articles have appeared as well in specialized journals, but it is important that this work be made available in more places, as it is here. The market liberalization of interest was separate from the formal structural adjustment reforms during the same period but it was clearly inspired by a similar philosophy. These articles present nuanced views of the on-the-ground effects of liberalization for real farmers and traders and appear not to be driven by pre-existing ideologies about the role of the market. Perhaps this is due, at least in part, to the active collaboration of Malian and American researchers. The final section looks at the road to democracy and decentralization in Mali. A. Clark looks at the contribution of the national conference, an institution found in many Francophone countries, to the creation of 
Reviews

electoral democracies. D. Rawson considers the contradictory tendencies toward centralization and decentralization in pre-colonial states, the French colonial administration, and the various post-independence governments as well as the challenges that these offer to plans for democratic decentralization. J.U. Davis looks at the opportunities for political socialization offered by diverse local groups and stresses the importance of capacity building to facilitate their inclusion in the democratic process. N. Mezey focuses on health and the way in which unequal gender roles constrain women's access to and use of health care, proposing some alternatives for health-care financing. R.J. Bingen's article looks at a variety of agricultural interest groups, their relationships with one other and with the central administration; he suggests that greater decentralization is likely to lead to greater access to the state by these groups because the nature of state centralization and concentration will change. Finally, C. Diarrah outlines the contemporary challenges to the institutionalization of Malian democracy and efforts by the government to meet them; although placed formally in a separate epilogue, this article fits thematically in the third section.

Several of these articles provide historical perspectives of Malian political change; although they are all valuable, D. Rawson's is particularly comprehensive and noteworthy. While recognizing the achievements that Mali has made in creating multi-party democracy, all the authors recognize the broader institutional and grassroots changes that need to occur in order to strengthen and deepen the process; elections are a only a necessary beginning. The articles also reflect some of the controversies that have marked interpretations of recent Malian history, for example, the extent to which previous regimes were actually able to carry out their centralizing schemes. So, while A. Clark emphasizes the repressiveness of the pre-democracy regime of Moussa Traoré, R.J. Bingen notes the ineffectiveness of central government attempts to transform the countryside.

This book is an important contribution for those interested in Mali, in French-speaking Africa, or the savanna countries of West Africa. Political and economic changes are occurring very quickly in Mali; a few of those discussed here have already been overtaken by events, yet these articles offer an invaluable evaluation of the situation at the end of the 1990s. Another outstanding feature of the collection as a whole is the dedication of the authors to explanatory frameworks that emphasize the factors within Mali that enabled contemporary change; while some might suggest that this gives insufficient attention to larger questions of the relationship of these changes to international political economy, it offers a refreshing corrective to analysts who slight the local context to privilege global issues. Overall this is a fine collection of works about the contemporary Malian political economy

\section{The Economic Evolution of American Health Care: From Marcus Welby to Managed Care by David D. Dranove. Princeton: Princeton University Press (2000), 211 pp.}

\section{Reviewed by Merrill Eisenberg, College of Public Health, The University of Arizona, Tucson.}

For all of you who are wondering just exactly how our health care system came to be so dreadful, David Dranove has the answers. Dranove was a student of Alain Enthoven, the Stanford based health care economist who was one of the architects of managed care as we know it in the US today. His book The Economic Evolution of American Health Care, tells the story of the recent paradigm shift in health care that has taken place over the past two decades. This book is not a critical analysis of the changes that have occurred - Dranove is a champion of paradigm. The book is an informative narrative - an emic description from an industry insider of how business and economic concerns rose to ascendancy and now control health care in the US. It is written for the lay reader and does an excellent job of explaining how we got to managed care and the issues that drive its continuing development.

Dranove, like his mentor Enthoven, is a champion of market forces. He not only explains, but celebrates the economic rationale for what appears to many Americans to be the erosion of both access to and the quality of basic health care services that has accompanied the transition to managed care in the US. From a market perspective, the problem with the traditional fee for service medical care system is the "shopping problem" (pp. 8-14) - the consumer has no incentive to shop for the best value in health care, since a third party is footing the bill. While he acknowledges that empirical evidence for improvement in health care quality and efficiency under managed care is largely equivocal, he defends the market approach with a fervor that borders on the religious.

Dranove traces the history of managed care back to the $1890 \mathrm{~s}$, when fraternal organizations and associations

Journal of Political Ecology

Vol. 82001 